\title{
FTY720 enhances TRAIL-mediated apoptosis by up-regulating DR5 and down-regulating Mcl-1 in cancer cells
}

\author{
Seon Min Woo', Bo Ram Seo ${ }^{1}$, Kyoung-jin Min ${ }^{1}$, Taeg Kyu Kwon ${ }^{1}$ \\ ${ }^{1}$ Department of Immunology, School of Medicine, Keimyung University, Dalseo-Gu, Daegu 704-701, South Korea \\ Correspondence to: \\ Kyoung-jin Min, e-mail: kyoungjin.min@gmail.com \\ Taeg Kyu Kwon, e-mail: kwontk@dsmc.or.kr
}

Keywords: FTY720, TRAIL, DR5, Mcl-1, apoptosis

Received: November 10, 2014

Accepted: February 24, 2015

Published: March 23, 2015

\section{ABSTRACT}

FTY720, Fingolimod, is a functional antagonist to the sphingosine-1-phoaphate (S1P) receptor and an inhibitor of sphingosine kinase 1. Here, we showed that a combination of FTY720 and TRAIL induced apoptosis in human renal, breast, and colon carcinoma cells. Most importantly, this combination had no effect on normal cells. Furthermore, the combined treatment with FTY720 and TRAIL reduced tumor growth in xenograft models. FTY720 up-regulated death receptor (DR)5 at posttranslational level. Knockdown of DR5 markedly blocked apoptosis induced by the combined treatment. FTY720 also inhibited Mcl-1 expression at the post-translational level. Over-expression of Mcl-1 blocked apoptosis induced by FTY720 and TRAIL. Interestingly, phospho-FTY720 and inhibitors of sphingosine kinase failed to enhance TRAIL-induced apoptosis. Thus, FTY720 enables TRAIL-induced apoptosis through up-regulation of DR5 and down-regulation of Mcl-1 in human cancer cells.

\section{INTRODUCTION}

Sphingosine-1-phosphate (S1P) increases cancer cell proliferation $[1,2]$ and tumorigenesis $[3,4]$ and reduces cancer cell death [5]. FTY720 is a synthetic sphingosine analogue and is phosphorylated by sphingosine kinase 2 [6]. Phospho-FTY720 binds sphingosine-1-phosphate (S1P) receptors and induces the internalization of S1P receptors. Therefore, FTY720 acts as a functional antagonist [7]. The immunosuppressant effects of FTY720 are well known. Among the $\mathrm{S} 1 \mathrm{P}$ receptors, $\mathrm{S}_{1} \mathrm{P}_{1}$ plays a crucial role in modulating lymphocyte migration and trafficking. Phospho-FTY720 binds $\mathrm{S}_{1} \mathrm{P}_{1}$ and then inhibits $\mathrm{T}$ lymphocyte egress from secondary lymphoid organs and migration into the transplanted graft, thereby suppressing inflammation [8]. In addition, novel functions of FTY720 have been reported. FTY720 induces cell death in multiple cancer cells, including cells from leukemia [9, 10], prostate [11], ovarian [12], and pancreatic [13] lines. Furthermore, FTY720 also sensitizes prostate cancer cells to radiotherapy [14], melanoma cells to cisplatin [15], and colon cancer cells to doxorubicin and etoposide [16]. Multiple FTY720-mediated apoptotic signaling pathways are independent of S1P signaling. The induction of protein phosphatase 2A [17], phospholipase C [18], and protein kinase $\mathrm{C}(\mathrm{PKC})$ activity was proposed to be involved in anti-cancer effects by FTY 720.

Tumor necrosis factor-related apoptosis-inducing ligand (TRAIL) is a known inducer of apoptosis in cancer cells but not normal cells [19]. When TRAIL induces cell death, it binds to death receptor (DR) 4 and DR5, which have increased expression levels relative to normal cells [20]. In contrast, normal cells highly express decoy receptor (DcR) 1 and DcR2, such that this death-signaling pathway is unable to activate intracellular apoptotic signaling [21-24]. However, the down-regulation of DR expression, the upregulation of anti-apoptotic proteins expression (c-FLIP(L), Bcl-2 and Bcl-xL) and the up-regulation of inhibitor of apoptosis proteins (IAPs) lead to resistance to TRAILmediated apoptosis in many cancer cells [25-29]. There are many studies that demonstrated related mechanisms of synergy between TRAIL and numerous agents [30-39]. Therefore, combination treatment with the TRAIL sensitizer could overcome TRAIL resistance.

In this study, we investigated whether FTY720 sensitized human renal carcinoma Caki cells to 
TRAIL-mediated apoptosis. We found that FTY720 enhanced TRAIL-mediated apoptosis in Caki cells through the up-regulation of DR5 and down-regulation of Mcl-1 expression. Collectively, our results suggest that combination treatment with FTY720 and TRAIL might be an effective therapeutic strategy for cancer treatment.

\section{RESULTS}

\section{Combined treatment with FTY720 and TRAIL induces apoptosis}

FTY720 is known to have anti-cancer effects in several types of cancer cells [9, 10]. Therefore, we investigated whether FTY720 can sensitize human renal carcinoma Caki cells to TRAIL-mediated apoptosis. Neither FTY720 nor TRAIL alone had any effect on apoptosis, but combined treatment with both FTY720 and TRAIL markedly enhanced the sub-G1 population and PARP cleavage, which are markers of apoptosis, in a dose-dependent manner; they also induced morphological changes (Figure 1A and 1B). Next, we examined whether combined treatment with FTY720 and TRAIL induces DNA fragmentation. We analyzed the DNA fragmentation induced by the combined treatment with FTY720 and TRAIL (Figure 1C) and detected the typical apoptotic nuclei (Figure 1D). Therefore, we examined whether combined treatment with FTY720 and TRAIL have synergistic effects. Combined treatment with various concentrations of FTY720 and TRAIL markedly reduced cell viability. The isobologram analysis suggested that the combined treatment with FTY720 and TRAIL has synergistic effects (Figure 1E). In addition, as shown in Figure 1F, FTY720 plus TRAIL increased caspase 2, 3, 8, and 9 activation (Figure 1F, and Supplementary Figure S1), and the pan-caspase inhibitor z-VAD markedly
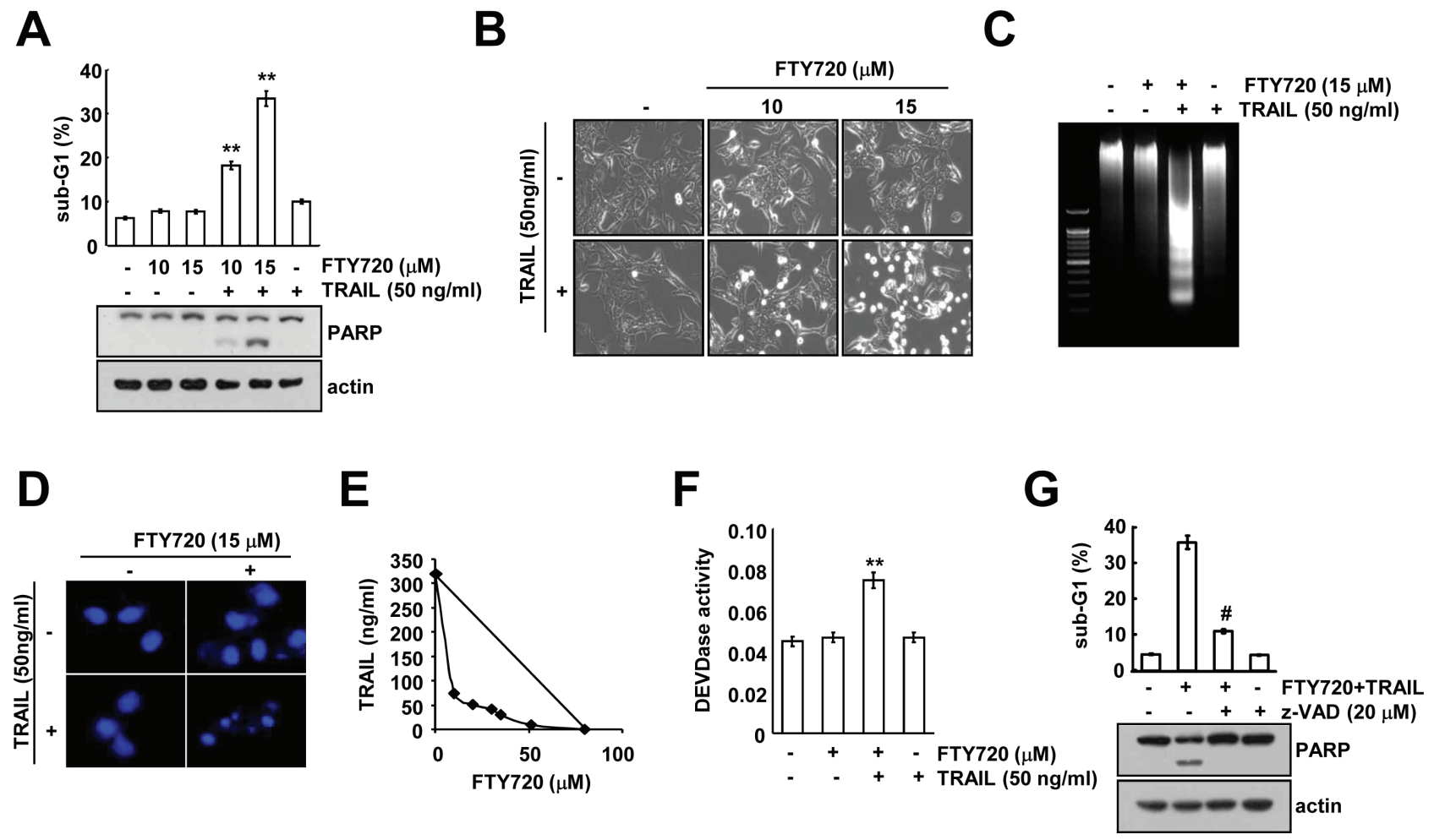

Figure 1: FTY720 sensitizes Caki cells to TRAIL-mediated apoptosis. (A) Caki cells were treated with $50 \mathrm{ng} / \mathrm{ml} \mathrm{TRAIL}$ in the presence or absence of the indicated concentrations of FTY720 for $24 \mathrm{~h}$. The sub-G1 fraction was measured by flow cytometry as an indicator of the level of apoptosis. The protein expression levels of PARP were determined by western blotting. The level of actin was used as a loading control. (B-D) Caki cells were treated with $50 \mathrm{ng} / \mathrm{ml}$ TRAIL in the presence or absence of the indicated concentrations of FTY720 for $24 \mathrm{~h}$. The cell morphology was examined using interference light microscopy (B). Fragmented DNA was extracted and analyzed on a $2 \%$ agarose gel (C). The condensation and fragmentation of the nuclei were detected by $4^{\prime}, 6^{\prime}$-diamidino-2-phenylindole staining (D). (E) Isoboles were obtained by plotting the combined concentrations of each drug required to produce $50 \%$ cell death. The straight line connecting the $\mathrm{IC}_{50}$ values obtained for the two agents when applied alone corresponded to the addition of their independent effects. Values below this line indicate synergy, whereas values above this line indicate antagonism. (F) Caki cells were treated with 50 $\mathrm{ng} / \mathrm{ml}$ TRAIL in the presence or absence of $15 \mu \mathrm{M}$ FTY720 for $24 \mathrm{~h}$. Caspase activities were determined with colorimetric assays using caspase-3 (DEVDase) assay kits. (G) Caki cells were treated with $15 \mu \mathrm{M}$ FTY720 plus $50 \mathrm{ng} / \mathrm{ml}$ TRAIL for $24 \mathrm{~h}$ in the presence or absence of $20 \mu \mathrm{M}$ z-VAD-fmk (z-VAD). The sub-G1 fraction was measured by flow cytometry. The protein expression levels of PARP and actin were determined by western blotting. The level of actin was used as a loading control. The values in A, F, and G represent the mean \pm SD from three independent samples. ${ }^{* *} p<0.01$ compared to the control. ${ }^{*} p<0.01$ compared to the co-treatment of FTY720 and TRAIL. 
inhibited apoptosis in the FTY720 plus TRAIL-treated cells (Figure 1G). Therefore, these data indicate that combined treatment with FTY720 and TRAIL can induce caspase-dependent apoptosis in human renal carcinoma Caki cells.

\section{FTY720 plus TRAIL induces apoptosis in other cancer cells, but not in normal cells}

To investigate the effects of FTY720 on TRAILmediated apoptosis, we co-treated other cancer cells with FTY720 and TRAIL. Combined treatment with FTY720 and TRAIL markedly induced apoptosis in renal cancer cells (ACHN and A498), human breast carcinoma cells (MDA-MB-231 cells) and human colon carcinoma (HT29) cells (Figure 2A and 2B). In contrast, combined treatment with FTY720 and TRAIL produced no morphological changes and had no effect on the induction of the sub-G1 population and PARP cleavage in normal mouse kidney cells (TMCK-1) (Figure 2C and 2D). These data indicate that combined treatment with FTY720 and TRAIL might induce apoptosis in cancer cells, but not in normal cells.

\section{Combined treatment with FTY720 and TRAIL inhibits tumor growth in vivo}

Next, we investigated whether combined treatment with FTY720 and TRAIL had anti-cancer effects in an in vivo xenograft model. Mice bearing tumors were treated with FTY720 alone, TRAIL alone, and FTY720 plus TRAIL. Combined treatment with FTY720 and TRAIL was found to markedly inhibit tumor growth compared with the vehicle control, FTY720 alone, or TRAIL alone (Figure 3A and 3B). Furthermore, we detected cell death using a TUNEL assay in FTY720 and TRAIL-treated samples (Figure 3C). In contrast, FTY720 and TRAIL treatment had no effect on the mouse weight (Figure 3D). These data suggest that combined treatment with FTY720 and TRAIL inhibits tumor growth and induces apoptosis in vivo.
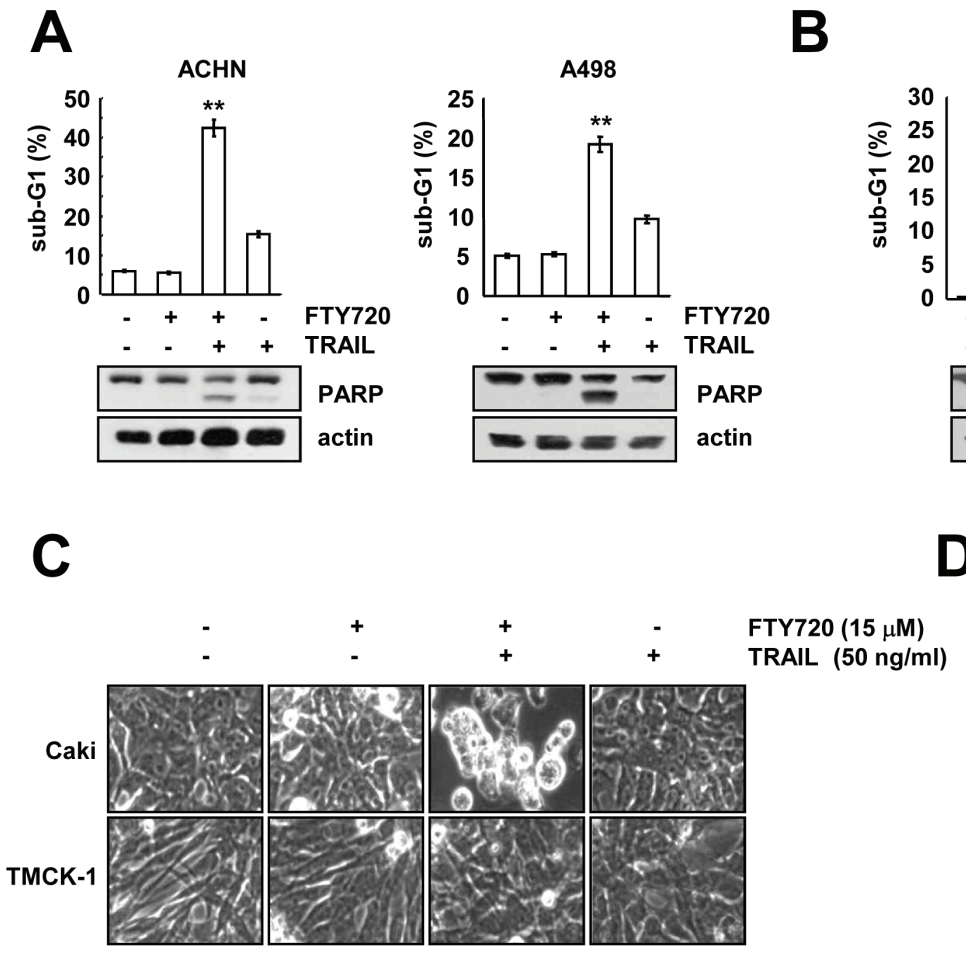
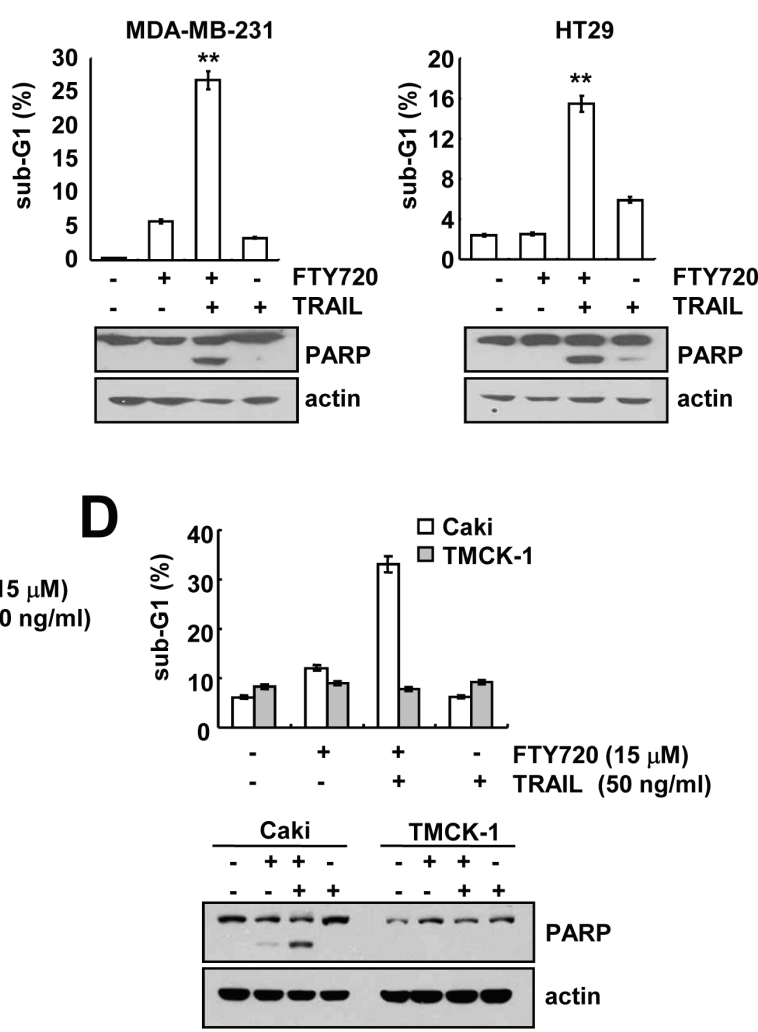

Figure 2: The effects of combined treatment with FTY720 plus TRAIL on apoptosis in other carcinoma cell lines and normal cells. (A and B) Renal carcinoma (ACHN and A498), breast carcinoma (MDA-MB231), and colon carcinoma (HT29) cells were treated with $50 \mathrm{ng} / \mathrm{ml}$ TRAIL in the presence or absence of $15 \mu \mathrm{M}$ FTY 720 for $24 \mathrm{~h}$. The level of apoptosis was assessed by measuring the sub-G1 fraction using flow cytometry. The protein expression levels of PARP and actin were determined by western blotting. The level of actin was used as the loading control. (C and D) Caki and TMCK-1 cells were treated with $50 \mathrm{ng} / \mathrm{ml}$ TRAIL in the presence or absence of $15 \mu \mathrm{M}$ FTY720 for $24 \mathrm{~h}$. The cell morphology was examined using interference light microscopy (C). The level of apoptosis was analyzed by measuring the sub-G1 fraction by flow cytometry (D, upper panel). The protein expression levels of PARP and actin were determined by western blotting. The level of actin was used as a loading control (D, lower panel). The values in $\mathrm{A}, \mathrm{B}$, and $\mathrm{D}$ represent the mean $\pm \mathrm{SD}$ from three independent samples. ${ }^{* *} p<0.01$ compared to control. 
A

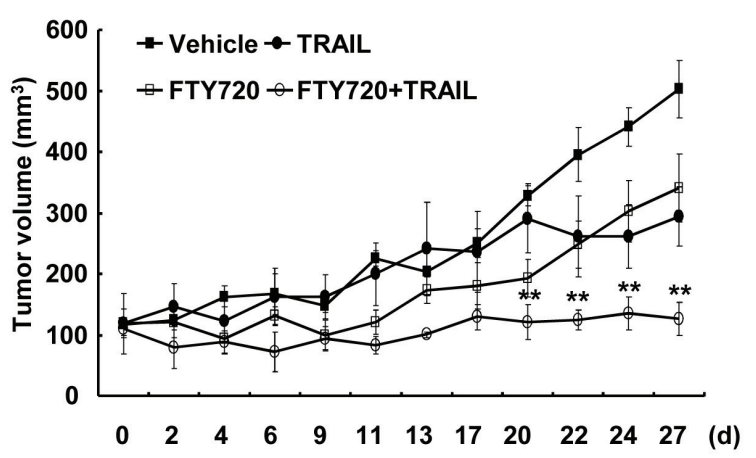

C

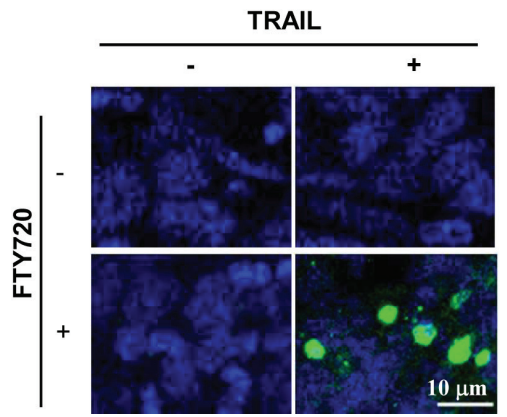

B

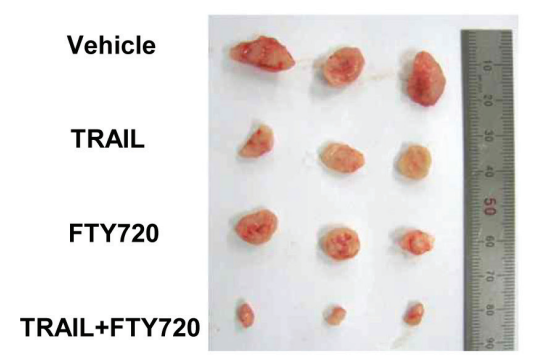

D

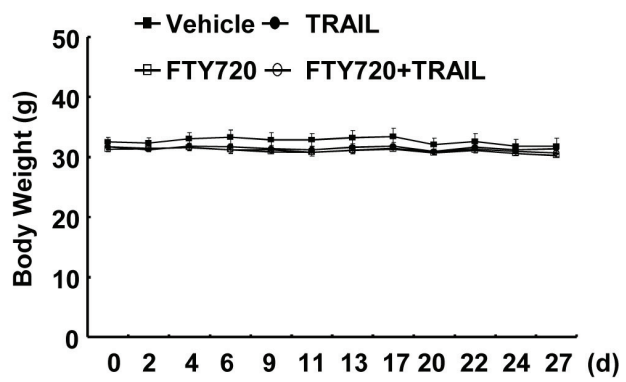

Figure 3: Tumor growth in vivo is reduced by the combined treatment with FTY720 and TRAIL. Nude mice were subcutaneously inoculated with Caki cells. Tumor volume was monitored during the following treatments: vehicle, FTY720 (7.5 mg/kg; i.p.), GST-TRAIL (3 mg/kg, i.p.), or FTY720 plus TRAIL for 27 days. (A) The graph shows changes in the tumor volume. There were 7 animals per group. The data are the means \pm SE $(n=7)$. (B) The size of the dissected-out tumors are shown. (C) Representative images of tumor sections analyzed by the TUNEL assay. Nuclear staining was performed with DAPI. (D) Bodyweight changes during the experiment. The values in $\mathrm{A}$ and $\mathrm{D}$ represent the mean $\pm \mathrm{SD}$. ${ }^{*} p<0.01$ compared to vehicle.

\section{Up-regulation of DR5 is associated with FTY720 and TRAIL-mediated apoptosis}

Death receptors (DRs) play key roles in TRAILmediated apoptosis $[22,24]$. Therefore, we determine whether FTY720 modulates the expression of DRs. FTY720 markedly induces DR5 expression, but not DR4 expression (Figure 4A). Next, we investigated whether FTY720 modulates DR5 expression at the transcriptional level. As shown in Figure 4B and 4C, FTY720 did not induce DR5 mRNA expression or promoter activity. Furthermore, FTY720 had no effect on the expression of the C/EBP homologous protein (CHOP), which is an important transcription factor that is involved in the regulation of DR5 mRNA expression (Supplementary Figure S2). Therefore, we investigated whether FTY720 modulates the protein stability of DR5. To investigate this possibility, Caki cells were treated with FTY720 for $18 \mathrm{~h}$, washed with FTY720, and then treated with or without FTY720 in the presence of $20 \mu \mathrm{g} / \mathrm{ml}$ cycloheximide (CHX) for the various indicated times. FTY720 was found to increase DR5 protein stability in Caki cells (Figure 4D). Next, to confirm the significance of the up-regulation of DR5 expression, Caki cells were transiently transfected with DR5 siRNA. The down-regulation of DR5 by siRNA markedly inhibited apoptosis caused by the combined treatment with FTY720 and TRAIL and PARP cleavage (Figure 4E). These results indicate that FTY720 induces the up-regulation of DR5 protein expression at the posttranslational level and that the FTY720-mediated DR5 upregulation is involved in the effects of FTY720 on TRAIL sensitization.

\section{The down-regulation of Mcl-1 is associated with FTY720 and TRAIL-mediated apoptosis}

Next, we investigated whether FTY720 modulates the expression of apoptosis regulatory proteins. The detected apoptosis regulatory proteins did not markedly change their expression levels, but Mcl-1 expression was reduced in a dose-dependent manner in the FTY720treated cells (Figure 5A). FTY720 induced the downregulation of Mcl-1 protein expression within $9 \mathrm{~h}$ (Figure 5A). Therefore, we examined whether FTY720 modulates Mcl-1 mRNA expression. However, FTY720 had no effect on Mcl-1 mRNA expression (Figure 5B).

When Caki cells were treated with or without FTY720 in the presence of $20 \mu \mathrm{g} / \mathrm{ml} \mathrm{CHX}$ for the various 
A

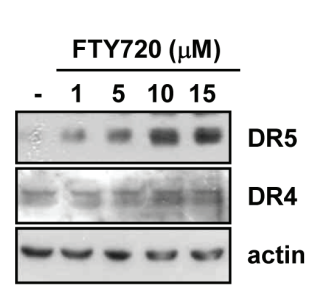

D
B

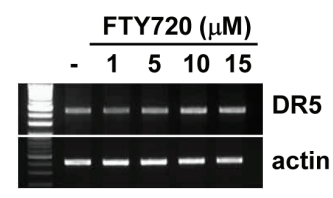

$\mathbf{E}$
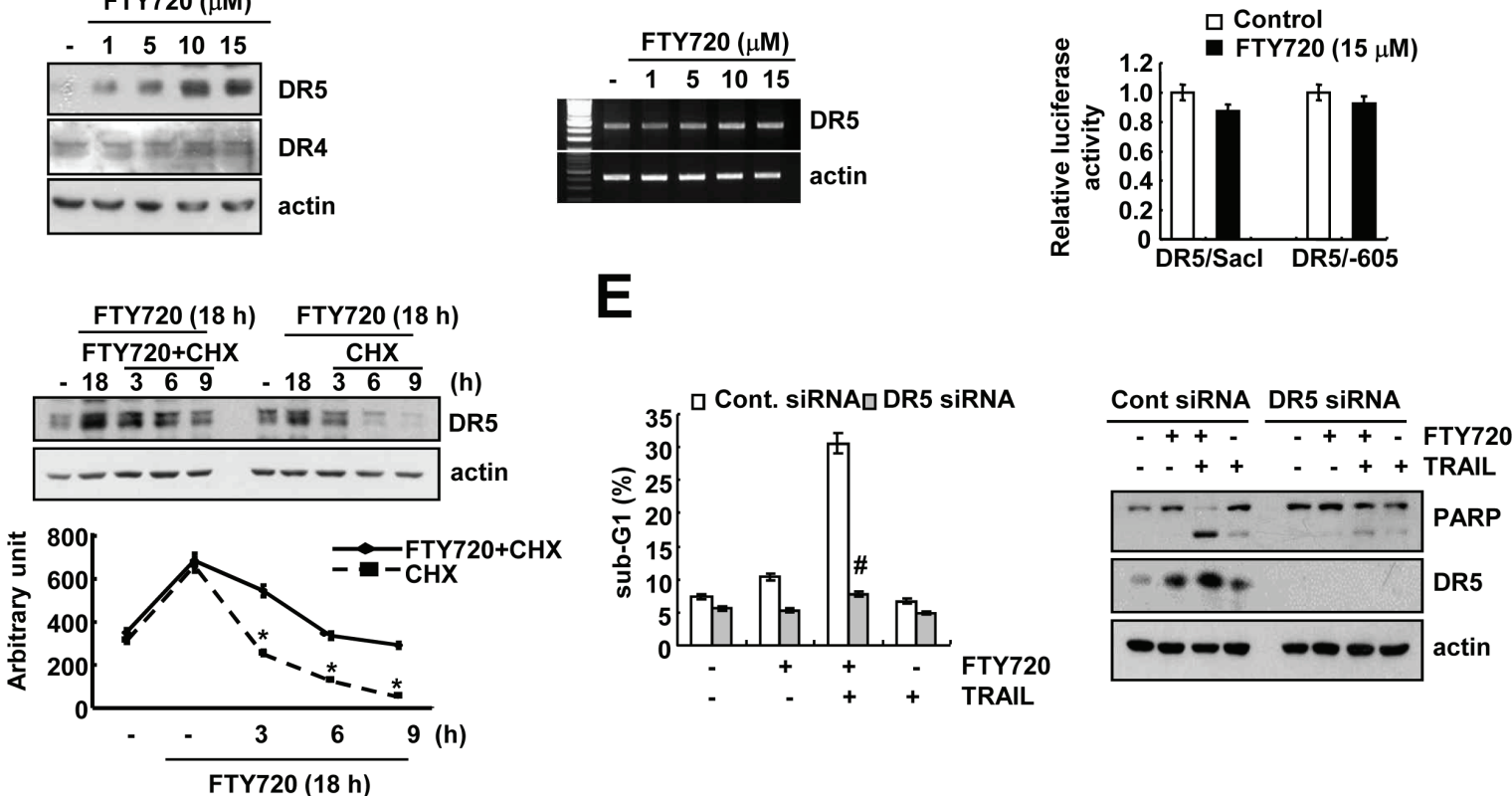

Figure 4: DR5 up-regulation by FTY720 contributes to the sensitization of Caki cells to TRAIL-mediated apoptosis. (A) Caki cells were treated with the indicated concentrations of FTY720 for 24 h. The protein expression levels of DR5, DR4, and actin were determined by western blotting. The level of actin was used as a loading control. (B) Caki cells were treated with the indicated concentrations of FTY720 for $24 \mathrm{~h}$. DR5 mRNA was determined using RT-PCR. (C) Caki cells were transiently transfected with plasmids (DR5/SacI and DR5/-605) harboring the luciferase gene under the control of the DR5 promoter. They were then treated with $15 \mu \mathrm{M}$ FTY720 for $18 \mathrm{~h}$. The cells were lysed, and the luciferase activity was measured. (D) Caki cells were treated with $15 \mu \mathrm{M}$ FTY720 for $18 \mathrm{~h}$, washed with PBS, and then treated with $20 \mu \mathrm{g} / \mathrm{ml}$ cyclohexamide (CHX) in the presence or absence of $15 \mu \mathrm{M}$ FTY720 for the indicated time periods. DR5 and actin protein levels were determined by western blotting. Actin expression was used as the loading control. The band intensity of the DR5 protein was measured using the public-domain JAVA image-processing program ImageJ (http://rsb.info.nih. gov/ij). (E) Caki cells were transiently transfected with DR5 siRNA and then treated with $50 \mathrm{ng} / \mathrm{ml}$ TRAIL in the presence or absence of $15 \mu \mathrm{M}$ FTY720 for $24 \mathrm{~h}$. The sub-G1 fraction was measured by flow cytometry. The protein expression levels of PARP, DR5 and actin were determined by western blotting. The level of actin was used as a loading control. The values in $(\mathrm{C}, \mathrm{D}$ and $\mathrm{E})$ represent the mean $\pm \mathrm{SD}$ from three independent samples. ${ }^{*} p<0.05$ compared to FTY720 plus CHX. ${ }^{*} p<0.01$ compared to FTY720 plus TRAIL-treated Cont.siRNA.

indicated time periods, FTY720 decreased the Mcl1 protein stability in Caki cells (Figure 5C). Previous studies reported that the degradation of $\mathrm{Mcl}-1$ was mainly modulated by the ubiquitin-proteasome pathway [40]. Therefore, we investigated whether FTY720 also modulates Mcl-1 protein expression via the ubiquitinproteasome pathway. First, we determine the effect of the proteasome inhibitor (lactacystin) on FTY720induced Mcl-1 degradation. As shown in Figure 5D, lactacystin markedly reversed the FTY720-induced downregulation of Mcl-1. Next, to determine whether the Mcl1 degradation caused by FTY720 treatment is dependent on ubiquitination, Caki cells were transiently transfected with Flag-Mcl-1 or Flag-Mcl-1 ${ }^{\mathrm{KR}}$, in which all 14 lysine residues were replaced with arginine. As shown in Figure 5E, CHX and FTY720 treatment led to the degradation of the Flag-Mcl-1 protein; the degradation of the Flag-Mcl-1 ${ }^{\text {KR }}$ protein is slower than the degradation of Flag-Mcl-1. These data indicate that FTY720-mediated Mcl-1 degradation is mainly ubiquitin-dependent, but that the involvement of the ubiquitin-independent pathway might also be associated with the degradation of Mcl-1 proteins. To investigate the mechanism of Mcl-1 degradation, we examined whether Mcl-1 expression was dependent on mitogen activated protein kinase (MAPK) activation in the FTY720-treated cells. However, the use of MAPK inhibitors did not block Mcl-1 down-regulation in the FTY720-treated cells (Supplementary Figure S3). Next, we investigated whether the down-regulation of Mcl-1 is critical for apoptosis following combined treatment with FTY720 and TRAIL. When Mcl-1 was over-expressed, the induction of apoptosis and cleavage of PARP caused by combined treatment with FTY720 and TRAIL decreased (Figure 5F and $5 \mathrm{G})$. To confirm the importance of the down-regulation of Mcl-1 expression on TRAIL sensitization, Caki cells were transiently transfected with Mcl-1 siRNA. The down-regulation of Mcl-1 expression by siRNA sensitized TRAIL-mediated apoptosis (Figure 5H). These results indicate that the down-regulation of $\mathrm{Mcl}-1$ has an important role on FTY720-mediated TRAIL sensitization. 

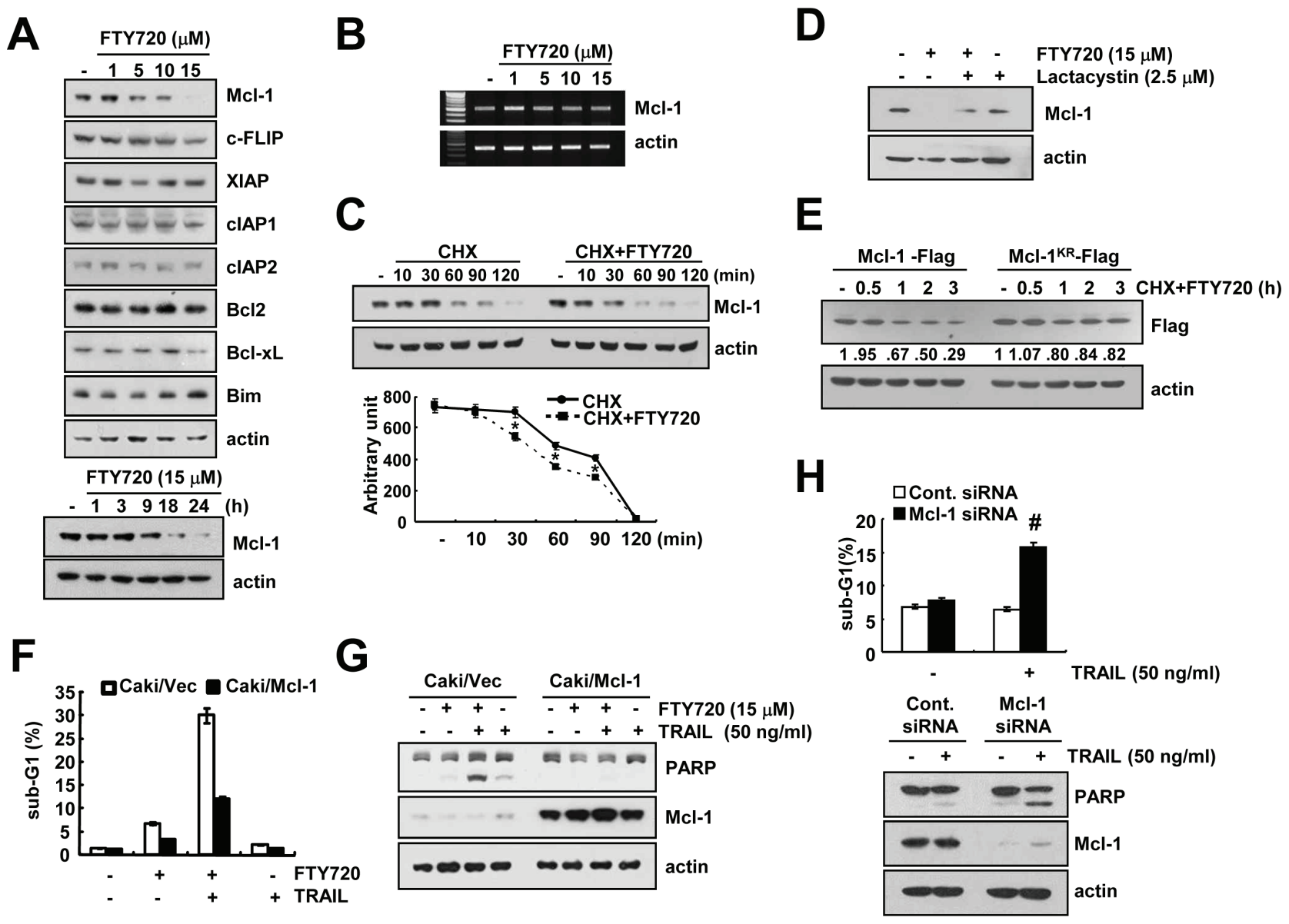

Figure 5: The down-regulation of Mcl-1 by FTY720 is associated with the induction of TRAIL-mediated apoptosis. (A) Caki cells were treated with the indicated concentrations of FTY720 for $24 \mathrm{~h}$ (upper panel) or the indicated time periods (lower panel). The protein expression levels of Mcl-1, c-FLIP, XIAP, cIAP1, cIAP2, Bcl-2, Bcl-xL, Bim, and actin were determined by western blotting. (B) Caki cells were treated with the indicated concentrations of FTY720 for $24 \mathrm{~h}$. The mRNA expression levels of Mcl-1 and actin were determined by RT-PCR. (C) Caki cells were treated with or without $15 \mu \mathrm{M}$ FTY720 in the presence of cyclohexamide (CHX) $(20 \mu \mathrm{g} / \mathrm{ml})$ for the indicated time periods. The Mcl-1 and actin protein levels were determined by western blotting. Actin expression was used as a loading control. The band intensity of the Mcl-1 protein was measured using the public domain JAVA image-processing program ImageJ (http:// rsb.info.nih.gov/ij). (D) Caki cells were pretreated with $2.5 \mu \mathrm{M}$ lactacystin, and then treated with $15 \mu \mathrm{M}$ FTY720 for $24 \mathrm{~h}$. The protein expression levels of Mcl-1 and actin were determined by western blotting. Actin expression was used as a loading control. (E) Caki cells

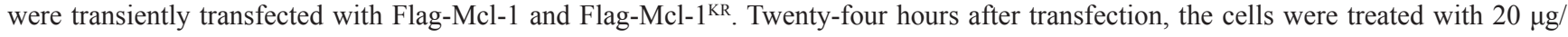
$\mathrm{ml}$ cyclohexamide (CHX) and $15 \mu \mathrm{M}$ FTY720 for the indicated time periods. Mcl-1 and actin protein levels were determined by western blotting. Actin expression was used as the loading control. (F and G) Vector cells (Caki/vector) and Mcl-1 overexpressed cells (Caki/ Mcl-1) were treated with $50 \mathrm{ng} / \mathrm{ml}$ TRAIL in the presence or absence of $15 \mu \mathrm{M}$ FTY720 for $24 \mathrm{~h}$. The level of apoptosis was analyzed by the sub-G1 fraction using flow cytometry (F). The PARP, Mcl-1 and actin protein levels were determined by western blotting. Actin expression was used as a loading control (G). (H) Caki cells were transiently transfected with Mcl-1 siRNA and then treated with $50 \mathrm{ng} /$ $\mathrm{ml}$ TRAIL for $24 \mathrm{~h}$. The sub-G1 fraction was measured by flow cytometry. The protein expression levels of PARP, Mcl-1 and actin were determined by western blotting. The level of actin was used as a loading control. The values in (C, F and H) represent the mean \pm SD from three independent samples. ${ }^{*} p<0.05$ compared to CHX. ${ }^{*} p<0.05$ compared to TRAIL-treated Cont.siRNA.

\section{The effect of FTY720-induced ROS production on TRAIL sensitization}

FTY720 induced intracellular reactive oxygen species (ROS) production in cancer cells [10, 41]. The induction of higher ROS levels is known to play an important role in TRAIL sensitization [42, 43]. Therefore, we investigated whether the induction of ROS levels by
FTY720 is associated with TRAIL sensitization. The levels of intracellular ROS production are markedly up-regulated in FTY720-treated cells (Figure 6A). However, ROS scavengers [trolox (trol), N-acetyl-L-cysteine (NAC), and glutathione ethyl ester (GEE)] were found to have no effect on FTY720 induced-DR5 up-regulation and Mcl-1 downregulation (Figure 6B). Furthermore, ROS scavengers did not affect apoptosis resulting from the combined treatment 
A
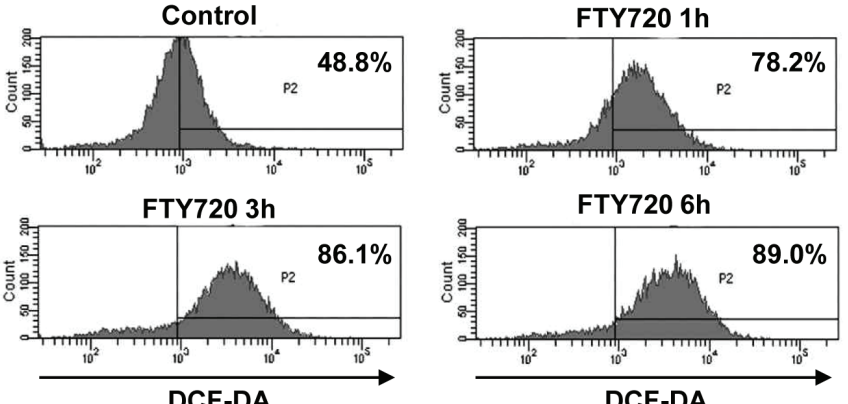

B

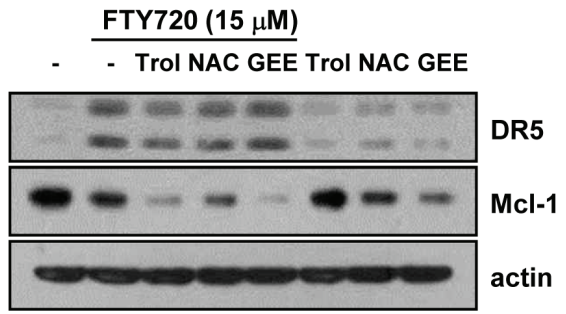

B
C

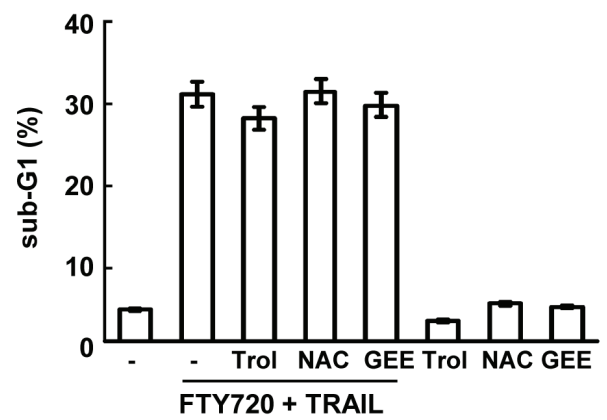

Figure 6: FTY720 and TRAIL-mediated apoptosis is independent of ROS signaling in Caki cells. (A) Caki cells were treated with $15 \mu \mathrm{M}$ FTY720 for the indicated time periods and loaded with $\mathrm{H}_{2}$ DCF-DA fluorescent dye. The $\mathrm{H}_{2}$ DCF-DA fluorescence intensity was detected by flow cytometry. (B) Caki cells were pretreated with $200 \mu \mathrm{M}$ trolox (Trol), $5 \mathrm{mM} \mathrm{NAC}$, and $2 \mathrm{mM}$ GEE for 30 min and then stimulated with $15 \mu \mathrm{M}$ FTY720 for $24 \mathrm{~h}$. The protein expression levels of DR5, Mcl-1 and actin were determined by western blotting. The level of actin was used as a loading control. (C) Caki cells were pretreated with $200 \mu \mathrm{M}$ trolox (Trol), $5 \mathrm{mM} \mathrm{NAC}$, and $2 \mathrm{mM}$ GEE for $30 \mathrm{~min}$, and then stimulated with $15 \mu \mathrm{M}$ FTY 720 plus $50 \mathrm{ng} / \mathrm{ml}$ TRAIL for $24 \mathrm{~h}$. Apoptosis was analyzed in the sub-G1 population by FACS analysis. The protein expression levels of PARP and actin were determined by western blotting. The level of actin was used as the loading control. The values in (C) represent the mean \pm SD from three independent samples.

with FTY720 and TRAIL or the PARP cleavage (Figure $6 \mathrm{C})$. These results suggest that effect of FTY720 on TRAIL sensitization is independent of the level of ROS production.

Taken together, our results demonstrate that FTY720 sensitizes cells to TRAIL-induced apoptosis through the up-regulation of DR5 and down-regulation of Mcl-1 expression in human renal Caki cells.

\section{DISCUSSION}

In this study, we demonstrated, for the first time, that FTY720 enhances TRAIL-mediated apoptosis in cancer cells, but not in normal cells. Furthermore, combined treatment with FTY720 and TRAIL reduced the tumor volume and induced apoptosis in a xenograft model. We found that the mechanism of FTY720-mediated TRAIL sensitization is associated with the up-regulation of DR5 protein stability and down-regulation of Mcl-1 protein stability. Although FTY720 markedly increased the intracellular ROS levels, FTY720-mediated TRAIL sensitization was found to be independent of ROS signaling. These findings suggest that FTY720 could be an attractive drug for TRAIL-sensitization.

FTY720 activates sphingosine-1-phosphate (S1P) receptors following phosphorylation by sphingosine kinase 2. Therefore, we investigated the involvement of S1P receptor signaling by assessing the impact of phospho-FTY720 on TRAIL sensitization. In contrast to FTY720, phospho-FTY720 had no effect on the TRAIL sensitization, up-regulation of DR5 expression, or down-regulation of Mcl-1 expression (Supplementary Figure S4A). Furthermore, sphingosine kinase inhibitors [N, N-dimethylsphingosine (DMS) and sphingosine kinase inhibitor (SKI)-178] and the down-regulation of sphingosine kinase 1 (SK1) by siRNA also had no effect on TRAIL sensitization (Supplementary Figure S4B and Supplementary S4C). These data suggest that the effects of FTY720 on TRAIL sensitization are independent of $\mathrm{S} 1 \mathrm{P}$ receptor signaling and the inhibition of sphingosine kinase 1.

FTY720 has been shown to have anti-cancer effects in several cancer cells, and its major anti-cancer effects are independent of S1P receptor signaling. First, FTY720 induces apoptosis in human hepatoma cells through the activation of PKC $\delta$ signaling [41]. FTY720 induces ROS production via the down-regulation of anti-oxidant enzyme (GST- $\pi$ ) expression and then activates PKC $\delta$ in human hepatoma cells [41]. However, the PKC $\delta$ inhibitor (rottlerin) cannot reverse apoptosis in the FTY720 and TRAIL-treated Caki cells (Supplementary Figure S4D). In our previous study, we reported that rottlerin induced apoptosis in human colon carcinoma cells through the 
up-regulation of DR5 and NAG-1 expression in a PKC $\delta$-independent manner $[44,45]$. Therefore, to confirm the effect of PKC $\delta$, Caki cells were transiently transfected with PKC $\delta$ siRNA and then treated with FTY720 plus TRAIL. The down-regulation of PKC $\delta$ by siRNA did not rescue apoptosis in FTY720 plus TRAIL-treated cells (data not shown). Therefore, the anti-cancer effects of FTY720 are independent of the activation of PKC $\delta$ in human renal carcinoma Caki cells. Second, FTY720 activates protein phosphatase (PP)2A. FTY720 induces cell death in chronic lymphocytic leukemia B cells and leukemia $\mathrm{T}$ cells via the activation of PP2A [17, 46]. However, FTY720 also induces caspase-independent cell death in acute lymphoblastic leukemia cells, but the effects of FTY720 are independent of PP2A activation. In other words, the mechanism of FTY720 could differ in different cell types. In our study, we also investigated whether PP2A activity is involved in FTY720 and TRAIL-mediated apoptosis. As shown in Supplementary Figure. S4D, a PP2A inhibitor (okadaic acid) had no effect on apoptosis. In addition, FTY720 also induced intracellular calcium concentrations through phospholipase $\mathrm{C}$ activation, which induced apoptosis in human promyelocytic leukemia cells [18]. We found that the FTY720-induced TRAIL sensitization is independent of phospholipase $\mathrm{C}$ activation (Supplementary Figure S4D). Although we failed to identify the intracellular mechanism of FTY720, FTY720 could sensitize human renal carcinoma (Caki, ACHN, and A498 cells), human breast carcinoma (MDA-MB-231), and human colon carcinoma (HT29) cells to TRAILmediated apoptosis. Therefore, this novel mechanism might be related to the anti-cancer effects of FTY720 in cancer cells. However, the mechanism by which FTY720 sensitizes cells to TRAIL-mediated apoptosis remains unclear and will require further investigation.

FTY720 induced the up-regulation of DR5 protein expression at the post-translational level (Figure 4D). Recently, Casitas B-lineage lymphoma (Cbl) was found to modulate the degradation of $\mathrm{DR}$ proteins. $\mathrm{Cbl}$ has been known to be a multi-adaptor protein and E3 ligase. Thus, receptor tyrosine kinases are ubiquitinated by $\mathrm{Cbl}$ and then degraded by proteasome or lysosome [47, 48]. Song et al. reported that $\mathrm{c}-\mathrm{Cbl}$ is responsible for the degradation of DRs by proteasomes and lysosomes in prostate carcinoma cells [49]. Yan et al., also reported that the down-regulation of Cbl-b by bufalin induced the up-regulation of DR expression in breast carcinoma cells [50]. In our study, we also detected a down-regulation of c-Cbl in FTY720-treated cells (data not shown). However, this down-regulation of $\mathrm{c}-\mathrm{Cbl}$ had no effect on DR5 expression or TRAIL sensitization in FTY720-treated cells (data not shown). Therefore, these results indicate that the up-regulation of DR5 by FTY720 is independent of the down-regulation of c-Cbl expression.

Collectively, these results suggest that FTY720 sensitizes TRAIL-mediated apoptosis through the up-regulation of DR5 expression and down-regulation of Mcl-1 expression in the human renal Caki cell line. Therefore, we suggest that FTY720 may be effectively used as a sensitizer of TRAIL.

\section{MATERIALS AND METHODS}

\section{Cell culture and materials}

Human renal carcinoma (Caki, ACHN, and A498), human breast carcinoma cells (MDA-MB-231), and human colon carcinoma cells (HT29) were obtained from the American Type Culture Collection (Manassas, VA, USA). The mouse kidney cells (TMCK-1) was a gift from Dr. T.J. Lee (Yeungnam University, Korea). The culture medium used throughout these experiments was Dulbecco's modified Eagle's medium (DMEM) or RPMI containing $10 \%$ fetal bovine serum (FBS), 20 mM HEPES buffer and $100 \mu \mathrm{g} / \mathrm{mL}$ gentamycin. FTY720 and phosphoFTY720 were purchased from Echelon Biosciences (Salt Lake City, UT, USA). The recombinant human TRAIL was purchased from KOMA Biotech (Seoul, Korea), and z-VAD-fmk, sphingosine kinase inhibitor (SKI), $\mathrm{N}$-acetyl-L-cysteine (NAC) and Trolox was obtained from Calbiochem (San Diego, CA, USA). Cyclohexamide, lactacystin, and glutathione ethyl ester (GEE) were purchased from Sigma Chemical Co. (St. Louis, MO, USA). N, N-dimethylsphingosine (DMS) was purchased from Cayman Chemical Company (Ann Arbor, MI, USA). GST-TRAIL cDNA plasmid was a gift from Dr. Kim YS (Ajou university, Korea). Anti-DR5, anti-DR4 anti-Bcl-2, anti-Bcl-xL, anti-Mcl-1, anti-cIAP1, anti-cIAP2, antiXIAP, and anti-PARP antibodies were purchased from Santa Cruz Biotechnology (Santa Cruz, CA, USA). Antic-FLIP antibody was obtained from ALEXIS Corporation (San Diego, CA, USA). Anti-Bim antibody was purchased from Millipore Corporation (Billerica, MA, USA). Antiactin and anti-Flag antibodies were obtained from Sigma (St. Louis, MO, USA). Flag-Mcl-1 (plasmid number: 32978) and Flag-Mcl-1 ${ }^{\mathrm{KR}}$ (plasmid number: 32979), which was deposited by Stewart, was purchased from addgene (Cambridge, MA, USA) [51].

\section{Flow cytometry analysis}

For flow cytometry, the cells were resuspended in $100 \mu \mathrm{l}$ of phosphate-buffered saline (PBS), and $200 \mu \mathrm{l}$ of $95 \%$ ethanol was added while the cells were being vortexed. Then, the cells were incubated at $4^{\circ} \mathrm{C}$ for $1 \mathrm{~h}$, washed with PBS, resuspended in $250 \mu \mathrm{l}$ of $1.12 \%$ sodium citrate buffer ( $\mathrm{pH} 8.4$ ) with $12.5 \mu \mathrm{g}$ of RNase and incubated for an additional $30 \mathrm{~min}$ at $37^{\circ} \mathrm{C}$. The cellular DNA was then stained by adding $250 \mu \mathrm{l}$ of a propidium iodide solution $(50 \mu \mathrm{g} / \mathrm{ml})$ to the cells for 30 min at room temperature. The stained cells were analyzed by fluorescent-activated cell sorting on a FACScan flow 
cytometer to determine the relative DNA content, which was based on the red fluorescence intensity.

\section{Western blot analysis}

For the Western blotting experiments, the cells were washed with cold PBS and lysed on ice in modified RIPA buffer (50 mM Tris- $\mathrm{HCl}$ pH 7.4, 1\% NP-40, 0.25\% Na-deoxycholate, $150 \mathrm{mM} \mathrm{NaCl}, 1 \mathrm{mM} \mathrm{Na}_{3} \mathrm{VO}_{4}$, and $1 \mathrm{mM} \mathrm{NaF})$ containing protease inhibitors $(100 \mu \mathrm{M}$ phenylmethylsulfonyl fluoride, $10 \mu \mathrm{g} / \mathrm{ml}$ leupeptin, 10 $\mu \mathrm{g} / \mathrm{ml}$ pepstatin, and $2 \mathrm{mM}$ EDTA). The lysates were centrifuged at $10,000 \times \mathrm{g}$ for $10 \mathrm{~min}$ at $4{ }^{\circ} \mathrm{C}$, and the supernatant fractions were collected. The proteins were separated by SDS-PAGE electrophoresis and transferred to Immobilon-P membranes. The specific proteins were detected using an enhanced chemiluminescence (ECL) Western blotting kit according to the manufacturer's instructions.

\section{DNA fragmentation assay}

After treatment with FTY720 plus TRAIL, Caki cells were lysed in a buffer containing $10 \mathrm{mM}$ Tris $(\mathrm{pH}$ 7.4), $150 \mathrm{mM} \mathrm{NaCl}, 5 \mathrm{mM}$ EDTA, and $0.5 \%$ Triton X-100 for $30 \mathrm{~min}$ on ice. Lysates were vortexed and cleared by centrifugation at $10,000 \mathrm{x}$ g for $20 \mathrm{~min}$. Fragmented DNA in the supernatant was extracted with an equal volume of neutral phenol:chloroform:isoamyl alcohol mixture (25:24:1) and analyzed electrophoretically on $2 \%$ agarose gels containing $0.1 \mu \mathrm{g} / \mathrm{ml}$ of ethidium bromide.

\section{4', 6'-diamidino-2-phenylindole staining (DAPI) for nuclei condensation and fragmentation}

To examine cellular nuclei, the cells were fixed with $1 \%$ paraformaldehyde on glass slides for $30 \mathrm{~min}$ at room temperature. After the fixation, the cells were washed

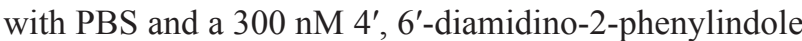
solution (Roche, Mannheim, Germany) was added to the fixed cells for $5 \mathrm{~min}$. After the nuclei were stained, the cells were examined by fluorescence microscopy.

\section{Determination of synergy}

The possible synergistic effect of FTY720 and TRAIL was evaluated using the isobologram method. In brief, the cells were treated with different concentrations of FTY720 and TRAIL alone or in combination. After $24 \mathrm{~h}$, XTT assay was employed to measure the cell viability using WelCount Cell Viability Assay Kit (WelGENE, Daegu, Korea). In brief, reagent was added to each well and was then measured with a multi-well plate reader (at $450 \mathrm{~nm} / 690 \mathrm{~nm}$ ). Relative survival was assessed and the concentration effect curves were used to determine the $\mathrm{IC}_{50}$ (the half-maximal inhibitory concentration) values for each drug alone and in combination with a fixed concentration of the second agent [52].

\section{Asp-Glu-Val-Asp-ase (DEVDase) activity assay}

To evaluate DEVDase activity, cell lysates were prepared after their respective treatments with TRAIL in the presence or absence of FTY720. Assays were performed in 96-well microtiter plates by incubating $20 \mu \mathrm{g}$ of cell lysates in $100 \mu \mathrm{l}$ of reaction buffer $(1 \%$ NP-40, 20 mM Tris-HCl, pH 7.5, 137 mM NaCl, 10\% glycerol) containing a caspase substrate [Asp-Glu-ValAsp-chromophore-p-nitroanilide (DVAD-pNA)] at 5 $\mu \mathrm{M}$. Lysates were incubated at $37^{\circ} \mathrm{C}$ for $2 \mathrm{~h}$. Thereafter, the absorbance at $405 \mathrm{~nm}$ was measured with a spectrophotometer.

\section{Animal}

Male BALB/c-nude mice, aged 5 weeks, were purchased from the Central Lab Animal Inc. (Seoul, Korea). All the mice were allowed 1 week to acclimatize to the surroundings before the experiments, and were kept at $25 \pm 2{ }^{\circ} \mathrm{C}$, with a relative humidity of $55 \pm 5 \%$ and a $12 \mathrm{~h}$ light-dark cycle. The study protocol was approved by the IRB Keimyung University Ethics Committee.

\section{in vivo xenograft model}

Each mouse was subcutaneously (s.c.) injected on each flank with Caki cells $\left(2 \times 10^{6}\right)$. After tumors had grown after approximately 2 weeks, 28 mice were randomly divided into four treatment groups: (1) vehicle alone, (2) FTY720 alone, (3) GST-TRAIL alone, and (4) FTY720 plus GST-TRAIL. FTY720 and GSTTRAIL were administered at $7.5 \mathrm{mg} / \mathrm{kg}$ and $3 \mathrm{mg} / \mathrm{kg}$, respectively. FTY720 and GST-TRIAL were prepared in PBS ( $\mathrm{pH}$ 7.4). The mice received an intraperitoneal (i.p.) injection of vehicle, FTY720 and GST-TRAIL. Treatment was administered three times a week for 4 weeks. The tumor size was measured three times a week using a Vernier's caliper (Mytutoyo Co., Japan) to measure two perpendicular diameters, and the tumor size was calculated using the equation (length $\times$ width $\left.^{2}\right) / 2$. The animals were sacrificed by cervical dislocation, and the tumors were collected for histological analysis. The tumors were fixed in 30\% formalin, embedded in OCT compound (Miles Inc., Elkhart, IN, USA) and cut into 20$\mu \mathrm{m}$ sections using a cryostat (SLEE International, Inc., New York, NY, USA).

\section{TUNEL assay}

Apoptosis in tumor cells was detected by terminal deoxynucleotide transferase (TdT)-mediated dUTP nickend labeling (TUNEL) assay. It was performed using the 
ApopTag Fluorescein In Situ Apoptosis Detection Kit (Millipore, Billerica, MA, USA) as the manufacturer's protocol.

\section{Reverse transcription polymerase chain reaction (RT-PCR)}

Total RNA was isolated using the TriZol reagent (Life Technologies; Gaithersburg, MD, USA), and the cDNA was prepared using M-MLV reverse transcriptase (Gibco-BRL; Gaithersburg, MD, USA) according to the manufacturers' instructions. The following primers were used for the amplification of human DR5, Mcl-1, and actin: DR5 (sense) 5'- AAG ACC CTT GTG CTC GTT GT-3' and (antisense) 5'- GAC ACA TTC GAT GTC ACT CCA-3', Mcl-1 (sense) 5'- GCG ACT GGC AAA GCT TGG CCT CAA-3' and (antisense) 5'- GTT ACA GCT TGG ATC CCA ACT GCA-3', and actin (sense) 5'- GGC ATC GTC ACC AAC TGG GAC - $3^{\prime}$ and (anti-sense) 5'- CGA TTT CCC GCT CGG CCG TGG -3'. The PCR amplification was carried out using the following cycling conditions: $94^{\circ} \mathrm{C}$ for $3 \mathrm{~min}$ followed by 17 (actin) or 23 cycles (DR5 and Mcl-1) of $94^{\circ} \mathrm{C}$ for $45 \mathrm{~s}, 58^{\circ} \mathrm{C}$ for $45 \mathrm{~s}$, $72^{\circ} \mathrm{C}$ for $1 \mathrm{~min}$, and a final extension at $72^{\circ} \mathrm{C}$ for $10 \mathrm{~min}$. The amplified products were separated by electrophoresis on a $1.5 \%$ agarose gel and detected under UV light.

\section{Plasmids, transfection and luciferase assay}

The pDR5/SacI plasmid [containing DR5 promoter sequence $(-2500 /+3)]$ and pDR5/ - 605 [containing DR5 promoter sequence $(-605 /+3)]$ were a gift from Dr Sakai T (Kyoto Prefectural University). Transient transfection was performed in 6-well plates.

One day before the transfection, Caki cells were plated at approximately $60-80 \%$ confluence. The DR5/ SacI and DR5/-605 promoter plasmid was transfected into the cells using Lipofectamine ${ }^{\mathrm{TM}} 2000$ (Invitrogen; Carlsbad, CA, USA). To assess the promoter-driven expression of the luciferase gene, the cells were collected and disrupted by sonication in lysis buffer (25 mM Tris-phosphate $\mathrm{pH}$ 7.8, 2 mM EDTA, 1\% Triton X-100, and $10 \%$ glycerol), and aliquots of the supernatants were used to analyze the luciferase activity according to the manufacturer's instructions (Promega; Madison, WI, USA).

\section{Small interfering RNA (siRNA)}

The DR5 siRNA used in this study was purchased from Invitrogen (Calsbad, CA, USA). Mcl-1 siRNA and sphingosine kinase 1 siRNA were purchased from Santa Cruz Biotechnology (Santa Cruz, CA, USA). The siRNA had the following sequences: DR5, AUC AGC AUC GUG UAC AAG GUG UCC C; and green fluorescent protein
[GFP (control)], AAG ACC CGC GCC GAG GUG AAG. Cells were transfected with siRNA oligonucleotides using Oligofectamine reagent (Invitrogen, Carlsbad, CA, USA) according to the manufacturer's recommendations.

\section{Stable transfection in Caki cells}

The Caki cells were transfected in a stable manner with the pFLAG-CMV4-Mcl-1, or control plasmid pcDNA 3.1 vector using Lipofectamine2000 as prescribed by the manufacturer (Invitrogen, Carlsbad, CA, USA). After $48 \mathrm{~h}$ of incubation, transfected cells were selected in primary cell culture medium containing $700 \mu \mathrm{g} / \mathrm{mL}$ G418 (Invitrogen). After 2 or 3 weeks, single independent clones were randomly isolated, and each individual clone was plated separately. After clonal expansion, cells from each independent clone were tested for expression levels of Mcl-1 by immunoblotting.

\section{Measurement of reactive oxygen species (ROS)}

Intracellular accumulation of ROS was determined using the fluorescent probes 2', 7'-dichlorodihydrofluorescein diacetate ( $\left.\mathrm{H}_{2} \mathrm{DCFDA}\right)$. $\mathrm{H}_{2}$ DCFDA is commonly used to measure ROS generation. Caki cells were treated with FTY720, and then cells were stained with the fluorescent dye $\mathrm{H}_{2}$ DCFDA for an additional $10 \mathrm{~min}$. Then, cells were trypsinized and resuspended in PBS, and fluorescence was measured at specific time intervals with a flow cytometer (BectonDickinson; Franklin Lakes, NJ, USA).

\section{Densitometry}

The band intensities were scanned and quantified using the gel analysis plugin for the open source software ImageJ 1.46 (Imaging Processing and Analysis in Java; http://rsb.info.nih.gov/ij).

\section{Statistical analysis}

The data were analyzed using a one-way ANOVA and post-hoc comparisons (Student-Newman-Keuls) using the Statistical Package for Social Sciences 22.0 software (SPSS Inc.; Chicago, IL, USA).

\section{ACKNOWLEDGMENTS}

This work was supported by an NRF grant funded by the Korea Government (MSIP) (2014R1A5A2010008 and NRF-2013R1A1A3009413).

\section{CONFLICTS OF INTEREST}

The authors declare no conflicts of interest. 


\section{REFERENCES}

1. Van Brocklyn J, Letterle C, Snyder P, Prior T. Sphingosine1-phosphate stimulates human glioma cell proliferation through Gi-coupled receptors: role of ERK MAP kinase and phosphatidylinositol 3-kinase beta. Cancer Lett. 2002; 181:195-204.

2. Thamilselvan V, Li W, Sumpio BE, Basson MD. Sphingosine-1-phosphate stimulates human Caco-2 intestinal epithelial proliferation via p38 activation and activates ERK by an independent mechanism. In Vitro Cell Dev Biol Anim. 2002; 38:246-253.

3. Pyne NJ, Pyne S. Sphingosine 1-phosphate and cancer. Nat Rev Cancer. 2010; 10:489-503.

4. Hsu A, Zhang W, Lee JF, An J, Ekambaram P, Liu J, Honn KV, Klinge CM, Lee MJ. Sphingosine-1-phosphate receptor-3 signaling up-regulates epidermal growth factor receptor and enhances epidermal growth factor receptormediated carcinogenic activities in cultured lung adenocarcinoma cells. Int J Oncol. 2012; 40:1619-1626.

5. Baran Y, Salas A, Senkal CE, Gunduz U, Bielawski J, Obeid LM, Ogretmen B. Alterations of ceramide/ sphingosine 1-phosphate rheostat involved in the regulation of resistance to imatinib-induced apoptosis in K562 human chronic myeloid leukemia cells. J Biol Chem. 2007; 282:10922-10934.

6. Zemann B, Kinzel B, Muller M, Reuschel R, Mechtcheriakova D, Urtz N, Bornancin F, Baumruker T, Billich A. Sphingosine kinase type 2 is essential for lymphopenia induced by the immunomodulatory drug FTY720. Blood. 2006; 107:1454-1458.

7. Brinkmann V. FTY720 (fingolimod) in Multiple Sclerosis: therapeutic effects in the immune and the central nervous system. Br J Pharmacol. 2009; 158:1173-1182.

8. Graler MH, Goetzl EJ. The immunosuppressant FTY720 down-regulates sphingosine 1-phosphate G-protein-coupled receptors. FASEB J. 2004; 18:551-553.

9. Li D, Zhang Y, Hu X, Cao W, Huang W. Role of extracelluar regulated protein kinases in FTY720-induced apoptosis of leukemia cell lines HL-60 and U937. J Huazhong Univ Sci Technolog Med Sci. 2004; 24:45-47.

10. Wallington-Beddoe CT, Hewson J, Bradstock KF, Bendall LJ. FTY720 produces caspase-independent cell death of acute lymphoblastic leukemia cells. Autophagy. 2011; 7:707-715.

11. Permpongkosol S, Wang JD, Takahara S, Matsumiya K, Nonomura N, Nishimura K, Tsujimura A, Kongkanand A, Okuyama A. Anticarcinogenic effect of FTY720 in human prostate carcinoma DU145 cells: modulation of mitogenic signaling, FAK, cell-cycle entry and apoptosis. Int J Cancer. 2002; 98:167-172.

12. Zhang N, Qi Y, Wadham C, Wang L, Warren A, Di W, Xia P. FTY720 induces necrotic cell death and autophagy in ovarian cancer cells: a protective role of autophagy. Autophagy. 2010; 6:1157-1167.

13. Shen Y, Cai M, Xia W, Liu J, Zhang Q, Xie H, Wang C, Wang X, Zheng S. FTY720, a synthetic compound from Isaria sinclairii, inhibits proliferation and induces apoptosis in pancreatic cancer cells. Cancer Lett. 2007; 254:288-297.

14. Pchejetski D, Bohler T, Brizuela L, Sauer L, Doumerc N, Golzio M, Salunkhe V, Teissie J, Malavaud B, Waxman J, Cuvillier O. FTY720 (fingolimod) sensitizes prostate cancer cells to radiotherapy by inhibition of sphingosine kinase-1. Cancer Res. 2010; 70:8651-8661.

15. Ishitsuka A, Fujine E, Mizutani Y, Tawada C, Kanoh H, Banno Y, Seishima M. FTY720 and cisplatin synergistically induce the death of cisplatin-resistant melanoma cells through the downregulation of the PI3K pathway and the decrease in epidermal growth factor receptor expression. Int J Mol Med. 2014; 34:1169-1174.

16. Xing Y, Wang ZH, Ma DH, Han Y. FTY720 enhances chemosensitivity of colon cancer cells to doxorubicin and etoposide via the modulation of P-glycoprotein and multidrug resistance protein 1. J Dig Dis. 2014; 15:246-259.

17. Matsuoka Y, Nagahara Y, Ikekita M, Shinomiya T. A novel immunosuppressive agent FTY720 induced Akt dephosphorylation in leukemia cells. Br J Pharmacol. 2003; 138:1303-1312.

18. Shinomiya T, Li XK, Amemiya H, Suzuki S. An immunosuppressive agent, FTY720, increases intracellular concentration of calcium ion and induces apoptosis in HL-60. Immunology. 1997; 91:594-600.

19. Wiley SR, Schooley K, Smolak PJ, Din WS, Huang CP, Nicholl JK, Sutherland GR, Smith TD, Rauch C, Smith CA, et al. Identification and characterization of a new member of the TNF family that induces apoptosis. Immunity. 1995; 3:673-682.

20. Ashkenazi A, Pai RC, Fong S, Leung S, Lawrence DA, Marsters SA, Blackie C, Chang L, McMurtrey AE, Hebert A, DeForge L, Koumenis IL, Lewis D, Harris L, Bussiere J, Koeppen H, et al. Safety and antitumor activity of recombinant soluble Apo2 ligand. J Clin Invest. 1999; 104:155-162.

21. Pan G, Ni J, Wei YF, Yu G, Gentz R, Dixit VM. An antagonist decoy receptor and a death domain-containing receptor for TRAIL. Science. 1997; 277:815-818.

22. Pan G, O'Rourke K, Chinnaiyan AM, Gentz R, Ebner R, Ni J, Dixit VM. The receptor for the cytotoxic ligand TRAIL. Science. 1997; 276:111-113.

23. Sheridan JP, Marsters SA, Pitti RM, Gurney A, Skubatch M, Baldwin D, Ramakrishnan L, Gray CL, Baker K, Wood WI, Goddard AD, Godowski P, Ashkenazi A. Control of TRAIL-induced apoptosis by a family of signaling and decoy receptors. Science. 1997; 277:818-821.

24. Walczak H, Degli-Esposti MA, Johnson RS, Smolak PJ, Waugh JY, Boiani N, Timour MS, Gerhart MJ, Schooley KA, Smith CA, Goodwin RG, Rauch CT. 
TRAIL-R2: a novel apoptosis-mediating receptor for TRAIL. EMBO J. 1997; 16:5386-5397.

25. Jin Z, McDonald ER, 3rd Dicker DT, El-Deiry WS. Deficient tumor necrosis factor-related apoptosis-inducing ligand (TRAIL) death receptor transport to the cell surface in human colon cancer cells selected for resistance to TRAILinduced apoptosis. J Biol Chem. 2004; 279:35829-35839.

26. Kelly MM, Hoel BD, Voelkel-Johnson C. Doxorubicin pretreatment sensitizes prostate cancer cell lines to TRAIL induced apoptosis which correlates with the loss of c-FLIP expression. Cancer Biol Ther. 2002; 1:520-527.

27. Ng CP, Zisman A, Bonavida B. Synergy is achieved by complementation with Apo2L/TRAIL and actinomycin D in Apo2L/TRAIL-mediated apoptosis of prostate cancer cells: role of XIAP in resistance. Prostate. 2002; 53:286-299.

28. Walczak H, Bouchon A, Stahl H, Krammer PH. Tumor necrosis factor-related apoptosis-inducing ligand retains its apoptosis-inducing capacity on Bcl-2- or Bcl-xLoverexpressing chemotherapy-resistant tumor cells. Cancer Res. 2000; 60:3051-3057.

29. Zhang Y, Zhang B. TRAIL resistance of breast cancer cells is associated with constitutive endocytosis of death receptors 4 and 5. Mol Cancer Res. 2008; 6:1861-1871.

30. Jung KJ, Min KJ, Bae JH, Kwon TK. Carnosic acid sensitized TRAIL-mediated apoptosis through down-regulation of c-FLIP and Bcl-2 expression at the post translational levels and CHOP-dependent up-regulation of DR5, Bim, and PUMA expression in human carcinoma caki cells. Oncotarget. 2015; 6:1556-1568.

31. Cao W, Li X, Zheng S, Zheng W, Wong YS, Chen T. Selenocysteine derivative overcomes TRAIL resistance in melanoma cells: evidence for ROS-dependent synergism and signaling crosstalk. Oncotarget. 2014; 5:7431-7445.

32. Chen JJ, Bozza WP, Di X, Zhang Y, Hallett W, Zhang B. H-Ras regulation of TRAIL death receptor mediated apoptosis. Oncotarget. 2014; 5:5125-5137.

33. Shin EA, Sohn EJ, Won G, Choi JU, Jeong M, Kim B, Kim MJ, Kim SH. Upregulation of microRNA135a-3p and death receptor 5 plays a critical role in Tanshinone I sensitized prostate cancer cells to TRAIL induced apoptosis. Oncotarget. 2014; 5:5624-5636.

34. Di X, Zhang G, Zhang Y, Takeda K, Rivera Rosado LA, Zhang B. Accumulation of autophagosomes in breast cancer cells induces TRAIL resistance through downregulation of surface expression of death receptors 4 and 5. Oncotarget. 2013; 4:1349-1364.

35. Saturno G, Valenti M, De Haven Brandon A, Thomas GV, Eccles S, Clarke PA, Workman P. Combining trail with PI3 kinase or HSP90 inhibitors enhances apoptosis in colorectal cancer cells via suppression of survival signaling. Oncotarget. 2013; 4:1185-1198.

36. Chen JJ, Mikelis CM, Zhang Y, Gutkind JS, Zhang B. TRAIL induces apoptosis in oral squamous carcinoma cells - a crosstalk with oncogenic Ras regulated cell surface expression of death receptor 5. Oncotarget. 2013; 4:206-217.

37. Chen JJ, Shen HC, Rivera Rosado LA, Zhang Y, Di X, Zhang B. Mislocalization of death receptors correlates with cellular resistance to their cognate ligands in human breast cancer cells. Oncotarget. 2012; 3:833-842.

38. Fulda S. Novel insights into the synergistic interaction of Bortezomib and TRAIL: tBid provides the link. Oncotarget. $2011 ; 2: 418-421$.

39. Eberhard Y, Gronda M, Hurren R, Datti A, MacLean N, Ketela T, Moffat J, Wrana JL, Schimmer AD. Inhibition of SREBP1 sensitizes cells to death ligands. Oncotarget. 2011; 2:186-196.

40. Zhong Q, Gao W, Du F, Wang X. Mule/ARF-BP1, a BH3only E3 ubiquitin ligase, catalyzes the polyubiquitination of Mcl-1 and regulates apoptosis. Cell. 2005; 121:1085-1095.

41. Hung JH, Lu YS, Wang YC, Ma YH, Wang DS, Kulp SK, Muthusamy N, Byrd JC, Cheng AL, Chen CS. FTY720 induces apoptosis in hepatocellular carcinoma cells through activation of protein kinase $\mathrm{C}$ delta signaling. Cancer Res. 2008; 68:1204-1212.

42. Min KJ, Seo BR, Bae YC, Yoo YH, Kwon TK. Antipsychotic agent thioridazine sensitizes renal carcinoma Caki cells to TRAIL-induced apoptosis through reactive oxygen speciesmediated inhibition of Akt signaling and downregulation of Mcl-1 and c-FLIP(L). Cell Death Dis. 2014; 5:e1063.

43. Woo SM, Min KJ, Kwon TK. Calyculin A causes sensitization to tumor necrosis factor-related apoptosis-inducing ligand (TRAIL)-induced apoptosis by ROS-mediated downregulation of cellular FLICE-inhibiting protein (c-FLIP) and by enhancing death receptor 4 mRNA stabilization. Apoptosis. 2012; 17:1223-1234.

44. Lim JH, Park JW, Choi KS, Park YB, Kwon TK. Rottlerin induces apoptosis via death receptor 5 (DR5) upregulation through CHOP-dependent and PKC deltaindependent mechanism in human malignant tumor cells. Carcinogenesis. 2009; 30:729-736.

45. Lim JH, Woo SM, Min KJ, Park EJ, Jang JH, Seo BR, Iqbal T, Lee TJ, Kim SH, Choi YH, Kwon TK. Rottlerin induces apoptosis of HT29 colon carcinoma cells through NAG-1 upregulation via an ERK and p38 MAPK-dependent and PKC deltaindependent mechanism. Chem Biol Interact. 2012; 197:1-7.

46. Liu Q, Zhao X, Frissora F, Ma Y, Santhanam R, Jarjoura D, Lehman A, Perrotti D, Chen CS, Dalton JT, Muthusamy N, Byrd JC. FTY720 demonstrates promising preclinical activity for chronic lymphocytic leukemia and lymphoblastic leukemia/lymphoma. Blood. 2008; 111:275-284.

47. Sanjay A, Horne WC, Baron R. The Cbl family: ubiquitin ligases regulating signaling by tyrosine kinases. Sci STKE. 2001; 2001:pe40.

48. Soubeyran P, Kowanetz K, Szymkiewicz I, Langdon WY, Dikic I. Cbl-CIN85-endophilin complex mediates ligandinduced downregulation of EGF receptors. Nature. 2002; 416:183-187. 
49. Song JJ, Szczepanski MJ, Kim SY, Kim JH, An JY, Kwon YT, Alcala MA Jr., Bartlett DL, Lee YJ. c-Cblmediated degradation of TRAIL receptors is responsible for the development of the early phase of TRAIL resistance. Cell Signal. 2010; 22:553-563.

50. Yan S, Qu X, Xu C, Zhu Z, Zhang L, Xu L, Song N, Teng Y, Liu Y. Down-regulation of Cbl-b by bufalin results in up-regulation of DR4/DR5 and sensitization of
TRAIL-induced apoptosis in breast cancer cells. J Cancer Res Clin Oncol. 2012; 138:1279-1289.

51. Stewart DP, Koss B, Bathina M, Perciavalle RM, Bisanz K, Opferman JT. Ubiquitin-independent degradation of antiapoptotic MCL-1. Mol Cell Biol. 2010; 30:3099-3110.

52. Tallarida RJ. Drug synergism: its detection and applications. J Pharmacol Exp Ther. 2001; 298:865-872. 